\title{
Durabilidad de ladrillos prensados de suelo-cemento
}

\section{Durability of compressed soil-cement bricks}

Fecha dec recepción: $1-X I I-99$

Fecha de aceptación: 8-VI-00
CECILIOACOSTAVALLE

Dpto. de Ingeniería Civil. Instituto Politécnico José A. Echeverría (La Habana)

\section{RESUMEN}

En el trabajo se evalúa la durabilidad de elementos aglomerados de suelo estabilizado. Se realiza un amplio número de ensayos encaminados a determinar el comportamiento frente a la acción de las cargas y la humedad de dos suelos con caracteristicas diferentes: uno limo-arcilloso y el otro arenoso. Este último presenta resultados muy favorables en ambas direcciones. El otro, con un posible uso más limitado.

Se emplea un método de diseño experimental del tipo rotacional cuadrático en hexágono, con réplicas en el punto central, el que garantiza la confiabilidad de los resultados de los ensayos, a la vez que disminuye la cantidad de especimenes a ensayar.

Se determina la humedad óptima a utilizar en las diferentes dosificaciones empleando la máquina compactadora, que resulta más racional que el ensayo Próctor ya que aplica el mismo tipo de energía y en la misma magnitud que la utilizada en la confección de los elementos.

Los resultados obtenidos muestran las diferencias del comportamiento de los elementos producidos con los dos tipos de suelos sometidos a ensayos de resistencia a la compresión, absorción y humedad y secado. Finalmente se le da una importancia mayor a los resultados de los ensayos de durabilidad en el posible uso de los ladrillos asi confeccionados.

\section{SUMMARY}

This papers shows the evaluation process of the durability of compressed soil-cement bricks. A great number of tests were made to determine the behavior of bricks when they are compression loaded and under the influence of moisture. Two different types of soils were used to produce the bricks, a lime-clay soil and a sand one. The sand soil is very resistant. The other one has a limited use.

An experimental design was used to test the bricks. It is a rotational and quadratic method with a hexagonal figure hich contains replicas at the central point. This method ensures the reliability of test results. Otherwise, it would reduce the amount of specimens necessary for the tests. The optimun moisture content is obtained by using a press machine. It is more rational than the standard Proctor compactation test, because it applies the same type and amount of energy used to produce the bricks.

The obtained results show the behavior differences between the two compressed soil-cement bricks subjected to the compression test, water absorption and wetting and drying tests. The durability tests results are very important in the possible use of the bricks produced.

\section{INTRODUCCIÓN}

Un estudio sobre las ventajas económicas que traería el aumento de la durabilidad de elementos aglomerados de suelos estabilizados, resulta una tarea compleja,

\section{INTRODUCTION}

A study of the economic advantages that would increase the durability of stabilized soil elements, is a complex task, mainly for the fers durability that 
sobre todo por las desventajas que éstos productos tienen, en cuanto a la durabilidad, cuando se comparan con bloques de hormigón y ladrillos de arcilla cocida. No se trata de comparar estos productos, sino estudiar, dentro del propio campo de los materiales y productos apropiados, los beneficios que aportaría una mayor durabilidad de éstos.

Se lleva a cabo un análisis, de acuerdo con los siguientes datos de partida:

a. Plan nacional anual de construcción de viviendas que utilicen paredes de ladrillos de suelo-cemento: 36.000 .

b. Vida útil supuesta de una vivienda convencional: 50 años.

c. Vida útil supuesta de una vivienda de estudio: 25 años.

d. Metros cuadrados de construcción de una vivienda tipo 56.

Se demuestra fácilmente que por cada año de vida útil que se pierda, por vivienda, el Estado Cubano deberá invertir alrededor de 460.000 pesos adicionales para satisfacer la demanda. Los incrementos anuales de consumo de cemento serían de 2.500 t y los de petróleo de $750 \mathrm{t}$.

Desde el año 1991, en el Centro de Estudios de Construcción y Arquitectura Tropical (CECAT), del ISPJAE, se viene estudiando, entre otras actividades, el comportamiento de ladrillos de suclos estabilizados precomprimidos, producidos en máquinas compactadoras manuales. La primera experiencia se inició en el año 1991 y sirvió para en la construcción de cuatro viviendas, en el municipio de Marianao, en La Habana. Se emplearon, en esa ocasión, paredes de ladrillos de suelo-cemento, utilizando un suelo calizoarcilloso proveniente de una cantera cercana al lugar de la obra (1).

En el año 1997 concluyeron cuatro trabajos de diplomatura de graduados de la Facultad de Ingeniería Civil, del ISPJAE; en tres de ellos se analizaron las características de ladrillos precomprimidos de suelocemento de tres suelos diferentes, y en otro de los trabajos se llevó a cabo el estudio de morteros de diferentes dosificaciones empleando uno de estos suelos. En el año 1998 se realizó una investigación más amplia, la que se expone en el presente trabajo.

\section{DISEÑO DE LA INVESTIGACIÓN}

Para el estudio de la durabilidad de los ladrillos de suclo-cemento se determinaron los parámetros o these products have, as compared with concrete blocks and ceramic bricks. Here we do not intent to compare these products, but to study in the own field of the appropriate materials, the benefits that could bring a greater durability of them.

If an analysis is carried out, in accordance with the following data:

a. National Annual Plan of housing construction that they use soil cement bricks walls: 36000.

b. Supposed useful life of a conventional housing: 50 years.

c. Supposed useful life of a housing of study: 25 years.

\section{d. Square meters of construction of a housing type 56.}

It is easily demonstrated that for every year of useful life that gets lost, for housing, the Cuban State will have invest around 460.000 additional pesos in order to satisfy the demand. The annual increments of cement consumption would be $2500 t$ and those of petroleum $750 \mathrm{t}$.

Since 1991, the Center for Studies in Construction and Tropical Architecture (CECAT), of the ISPJAE, among its activities, investigates the behavior of compressed bricks of stabilized soil, produced in manual compressing machines. The first experience began in 1991 in the construction of four housings, in the municipality of Marianao in Havana. Soil cement bricks walls were used in that occasion, using a calcareous-claily soil gotten from a quarry near the place of construction (1).

In 1997 concluded four works of diploma of Civil Engineering students; in three of them were analyzed pressed bricks characteristics of three different soils, and in another of the works the study of mortars of several dosages was carried out using one of these soils. In 1998 was carried out a wider investigation which is explained here in.

\section{RESEARCH DESIGN}

For the study of the durability of soil cement pressed bricks it was determined the characteristics to 
características a medir en cada caso, así como los factores y niveles que se utilizarían en los ensayos.

Se seleccionó un diseño experimental cuadrático, con los puntos experimentales situados en los extremos de un hexágono y en el centro.

Para la confección de los bloques se emplearon dos tipos de suelo, uno de tipo arcilloso y otro arenoso, cemento Portland, cal utilizada como plastificante en el suelo arcilloso y agua. Los factores a variar fucron el cemento y el agua. Los ladrillos se fabricaron en una máquina TERSTARAM de doble compresión de patente belga.

Los niveles de variación del cemento serán: 0, 2,5, 5 , 7,5 y $10 \%$ y los del agua serán los que se determinen en el ensayo similar al Próctor, realizado en la prensa.

Ensayos a realizar a los ladrillos:

- Absorción de agua

- Resistencia a compresión seca y saturada

- Humedad y secado.

Edades de los ensayos: absorción de agua a 7 días; humedad y secado a 14 días y resistencia a compresión a 7 y 28 días.

No se encontró un trabajo de investigación que haga un estudio integral de la durabilidad de elementos de suelos estabilizados. De forma aislada, algunos autores recomiendan los ensayos a realizar para el estudio de la durabilidad, pero no en todos los casos se proponen los indicados (2-4).

Se ha comprobado que no existe un espectro amplio de normas que contengan el saber sobre las construcciones con suelos estabilizados. De acuerdo con la documentación consultada, CRAterre, como institución, tiene una vasta experiencia en el tema y ha publicado un amplio tratado sobre el mismo, no obstante no constituyen documentos normativos. La ASTM (5) establece las normas para los ensayos de suelo-cemento, pero no establece especificaciones.

\section{CARACTERÍSTICAS DE LOS MATERIALES}

\section{Clasificación de los suelos (Tabla 1)}

La cal utilizada es de desecho, procedente de la fábrica de acetileno de La Habana.

El cemento Portland P-350 procede de la fábrica de Artemisa, de la provincia de La Habana. measure in each case, as well as the factors and levels that would be used in the investigation design.

A quadratic experimental design was selected with the experimental points located in the ends and centre of an hexagon.

Two types of soils were used to produce the bricks, a clay and other sand. also were used Portland cement, lime as plastificant and water. The varied factors were cement and water. The bricks were fabricated in a TERSTARAM machine with double compression and belgian patent.

The cement variation levels were: $0,2.5,5,7.5$ and $10 \%$, the water variation levels will be those determined in the similar to the standard Proctor

- Test to carry out to the pressed bricks:

- Water absorbtion test.

- Dry compressive strength test

- Wetting and drying test.

Ages of the tests: the water absorption test 7 days, the wetting and drying test 14 days and the compressive strength test 7 and 28 days.

Search of investigation done, showed that no one makes an integral study of the durability of soil estabilized elements. Some authors recommend the tests to carry out for the study of the durability, but not in all the cases they proposes the indicators (2-4).

It has been proven that a wide spectrum of standard that could integrate the knowledge on the constructions with estabilized soils, does not exist in accordance with the consulted documentation, althoug CRAterre, as institution, has a vast experience in the theme and it has published a wide treaty on it, they nevertheles don't constitute normative document. The ASTM (5) established the standards for the tests of stabilized soils but has no standards for specification.

\section{CHARACTERISTICS OF MATERIALS}

\section{Soils classification (Table 1)}

The lime used in this research work is of waste, gotten from Havana acetylene plant.

The Portland cement P-350 is gotten from Artemisa factory of Havana province. 
TABLA 1 (TABLE 1)

Clasificación de los suelos

(Soils classification)

\begin{tabular}{||c|c|c||}
\hline & \multicolumn{2}{|c||}{ Clasificación (Classification) } \\
\hline Suelo (Soil) & $\begin{array}{c}\text { Método H.R.B. } \\
(\text { H. R. B. method) }\end{array}$ & $\begin{array}{c}\text { Método SUCS } \\
\text { (USCS method) }\end{array}$ \\
\hline Toledo & A-7-5 (13) & $\begin{array}{c}\text { CH. Arcillas muy plásticas } \\
\text { (CH. Very plastic clays) }\end{array}$ \\
\hline El Globo & A-4 (1) & $\begin{array}{c}\text { Arena arcillo-gravosa } \\
\text { (SM. Sand silt) }\end{array}$ \\
\hline
\end{tabular}

TABLA 2 (TABLE 2)

Humedades óptimas

(Optimum moistures)

\begin{tabular}{|c|c|c||}
\hline Suelo (Soil) & $\begin{array}{c}\text { Humedad óptima (cemento 0\%) } \\
\text { (Optimum moisture, content 0\% cement) }\end{array}$ & $\begin{array}{c}\text { Humedad óptima (cemento 10\%) } \\
\text { (Optimum moisture, content 10\% cement) }\end{array}$ \\
\hline Toledo & 33,5 & 29,5 \\
\hline El Globo & 16 & 19 \\
\hline
\end{tabular}

Ambos materiales cumplicron los parámetros establecidos por las normas cubanas. Para determinar la humedad óptima de los suelos se realizó un ensayo similar al Próctor, empleando la máquina conformadora de los ladrillos, la que trasmite la energía de forma estática. El ensayo Próctor se realiza aplicando una energía diferente, en magnitud, a la de la máquina conformadora, además de dinámica.

Las humedades óptimas se muestran en laTabla 2.

Se observa cómo el suelo arcilloso Toledo, con $10 \%$ de cemento, requiere menor humedad que sin estabilizante. Esto se debe a que al adicionar cemento se está sustituyendo arcilla, con mayor superficie específica que el cemento Portland.

Se confeccionaron muestras constituidas por cinco ladrillos de $32 \times 11 \times 8 \mathrm{~cm}$ para ser sometidos a los ensayos establecidos con anterioridad, a las edades indicadas. Estas muestras permanecieron durante 28 días en una cámara húmeda.

\section{RESULTADOS Y ANÁLISIS DE LOS ENSAYOS}

Las Tablas 3 y 4 presentan los resultados de los ensayos con respecto a los suelos El Globo y Toledo.
Both materials completed the parameters established by the cuban standards. In order to determine the estabilized soil optimun moisture content it was carried out a similar to Proctor compactation test using the Terstaran press, that trasmits the energy of static form. The standard Proctor compactation test is carried out applying a different energy in magnitude to that the machine press and besides it has a dynamic character.

The optimum moistures obtained are presented in Table 2.

The claily soil Toledo with $10 \%$ of cement require less moisture content than without estabilizer. This is due to he fact that added cement has a minor specific surface than the clay

Unit samples with five pressed bricks of $32 x 11 \times 8 \mathrm{~cm}$ were make in order to be subjected to the established previously tests, in the indicated ages. These samples remained for 28 days in a camera for wetting.

\section{ANALYSIS AND TEST RESULTS}

Tables 3 and 4 shows the results of compressive strenght and the durability tests of soils El Globo and Toledo. 
TABLA 3 (TABLE 3)

Resultados de los ensayos correspondientes al suelo El Globo

(Test results of soil El Globo)

\begin{tabular}{|c|c|c|c|c|c|}
\hline $\begin{array}{l}\% \text { cemento } \\
\text { (cement \%) }\end{array}$ & $\begin{array}{c}\% \text { agua } \\
\text { (waler } \%)\end{array}$ & $\begin{array}{c}\mathrm{R}_{c} \text { seca } 7 \text { días } \\
(D r y ' C . S t .7 \text { days }) \\
\mathrm{MPa}\end{array}$ & $\begin{array}{c}\left.\mathrm{R}_{\mathrm{c}} \text { seca } 28 \text { días }\right) \\
(D \eta C . S t .28 \text { day's }) \\
\mathrm{MPa}\end{array}$ & $\begin{array}{c}\% \text { absorción agua } \\
7 \text { dias } \\
\text { (water absorption } \\
7 \text { da)s \%) }\end{array}$ & $\begin{array}{l}\% \text { pérdidas de peso (H y S) } 14 \text { dias } \\
\text { losses of weigh (W \& D) } 14 \text { days \%) }\end{array}$ \\
\hline 0 & 17.5 & 0,13 & 0,37 & 19.7 & 100 \\
\hline 2,5 & 19 & 1,09 & 1,66 & 8,60 & 20,31 \\
\hline 7,5 & 19 & 2,55 & 4,35 & 5,75 & 2,82 \\
\hline 10 & 17,5 & 3,12 & 4,91 & 3,92 & 2,84 \\
\hline 7,5 & 16 & 3,24 & 4,42 & 6,88 & 4,96 \\
\hline 2,5 & 19 & 0,91 & 1,63 & 7,95 & 16,21 \\
\hline 5 & 17,5 & 1,85 & 3,13 & 3,16 & 6,25 \\
\hline 5 & 17,5 & 1,82 & 2.74 & 6.2 & 6,53 \\
\hline 5 & 17.5 & 1,67 & 3,48 & 5.73 & 7,12 \\
\hline 5 & 17,5 & 1,86 & 2,60 & 3.2 & 7,28 \\
\hline
\end{tabular}

TABLA 4 (TABLE 4)

Resultados de los ensayos correspondientes al suelo Toledo

(Test results of soil Toledo)

\begin{tabular}{|c|c|c|c|c|c|}
\hline $\begin{array}{l}\% \text { cemento } \\
\text { (cement \%) }\end{array}$ & $\begin{array}{c}\% \text { agua } \\
\text { (water } \%)\end{array}$ & $\begin{array}{c}\mathrm{R}_{c} \text { seca } 7 \text { dias } \\
(D \eta y \text { C. St. } 7 \text { days }) \\
\mathrm{MPa}\end{array}$ & $\begin{array}{c}\mathrm{R}_{\mathrm{c}} \text { seca } 28 \text { días } \\
(D r y \text { C. St. } 28 \text { days }) \\
\mathrm{MPa}\end{array}$ & $\begin{array}{c}\% \text { agua de absorción } \\
7 \text { dias } \\
\text { (water absorption } \\
7 \text { da):s } \% \text { ) }\end{array}$ & $\begin{array}{l}\text { \% pérdidas de peso (H y S) } 14 \text { días } \\
\text { (losses of n'eigh (W \& D) } 14 \text { da)'s \%) }\end{array}$ \\
\hline 0 & 31,5 & 4,6 & 5,4 & 53,72 & 100 \\
\hline 10 & 31.5 & 17.8 & 26,6 & 15,72 & $*$ \\
\hline 7,5 & 33,5 & 15,9 & 23,9 & 13,85 & * \\
\hline 7,5 & 29,5 & 16,5 & 23,5 & 17,29 & $*$ \\
\hline 2,5 & 33,5 & 10,7 & 16,2 & $\ldots$ & 100 \\
\hline 2,5 & 29,5 & 10,3 & 11,4 & 15,31 & 100 \\
\hline 5 & 31,5 & 13,6 & 18,7 & 14,89 & 100 \\
\hline 5 & 31,5 & 13,9 & 19,7 & 15,08 & 100 \\
\hline 5 & 31,5 & 12,6 & 16,9 & 15,10 & 100 \\
\hline 5 & 31,5 & 13,2 & 18,8 & 14,66 & 100 \\
\hline
\end{tabular}

* Soportaron 5 ciclos de humedad y secado

* (Supporl 5 cycles of moisture and drying) 
a) Resistencia a compresión seca.

Se acepta la recomendación de la Comisión de Desarrollo y Aplicación de Suelos Estabilizados (CODASE) (6) de que los ladrillos deberán tener una Resistencia a Compresión a 7 días de 2 Mpa.

. Las dosificaciones del suelo El Globo de 7,5 y $10 \%$ de cemento cumplen con las recomendaciones de la CODASE para 7 y 28 días, mientras que la de $5 \%$ está muy cerca de lo establecido para los 7 días.

- Las dosificaciones de 7,5 y $10 \%$ de cemento del suelo El Globo cumplen además, con lo establecido por Elena Ochoa (7), Facultad de ArquitecturaCECAT(1) y CODASE a los 28 días.

. Ninguna dosificación del suelo Toledo cumple con las recomendaciones de la CODASE para los 7 días, sin embargo, la de $10 \%$ de cemento está muy cercana y cumple con la de los 28 días.

- Las dosificaciones de 7,5 y $10 \%$ de cemento del suelo Toledo cumplen las recomendaciones dadas por $(1,3$ y 6$)$ para 28 días.

b) Absorción de agua

Para la dosificación del suelo El Globo con 10\% de cemento son satisfechas las recomendaciones de Norton (2) y las restantes cumplen lo establecido por (8).

Las dosificaciones del suelo Toledo no cumplen lo establecido por (2) ni por (8) en ninguna dosificación.

c) Pérdidas de peso por humedad y secado.

El suelo Toledo no cumple con ninguna de las recomendaciones planteadas, mientras que sólo en el caso de las dosificaciones de 7,5 y $10 \%$ de cemento llegaron al quinto ciclo. Para el suelo El Globo las dosificaciones con $5,7,5$ y $10 \%$ de cemento cumplen con lo establecido en (3) y (8).

\section{CONCLUSIONES}

1. Los criterios de durabilidad deberán ser tomados como definitorios en el diseño de estructuras realizadas con suelos estabilizados, a la vez que deberán ser recogidos por la CODASE, entidad que se encarga de establecer los requerimientos del suclocemento en Cuba.

2. Los ladrillos realizados con el suelo arenoso de la cantera El Globo cumplen con las especificaciones de a) Dry compressive strength.

It is accepted the recommendation of the Commission of Development and Application of Stabilized Soils (CODASE) (6) that the pressed bricks will have a compressive strength to 7 days of $2 \mathrm{Mpa}$.

. The dosage of the soil El Globo of 7.5 and $10 \%$ of cement, fulfill the recommendations of the CODASE for 7 and 28 days, while that the result of $5 \%$ of cement it is very near the established for the 7 days.

. The dosages of 7.5 and $10 \%$ of cement of the soil El Globo also cumplies, with the established by Elena Ochoa (7), Faculty of Arquitectura-CECAT (I) and CODASE to the 28 day's.

- No dosage of the soil Toledo, fulfills the recommendations of the CODASE for 7 days, however, that of $10 \%$ of cement it is very close and he results are congruent in 28 days.

. The dosages of 7.5 and $10 \%$ of cement of the soil Toledo cumplies the considered recommendations ( 1 , 3 and 6) for 28 days.

b) Water absorption

For the soil El Globo the dosage with 10\% of cement the recommendations of Norton (2) are satisfied and the remaining dosages fulfill with (8).

No dosages of the soil Toledo fulfills the established in (2) neither in (8).

\section{c) Losses of weigth for weiting and drying}

The soil Toledo doesn't fulfill any of the exposed recommendations, while only in the case of the dosages of 7,5 and 10\% of cement it arrived to the fifth cycle. For the soil El Globo the dosages with 5, 7.5 and $10 \%$ of cement fulfill established in (3) and (8).

\section{CONCLUSIONS}

1. It is obligatory to take accord the durability in the design of structures carried out with stabilized soils, at the same time that they will be taken up for the CODASE, entity that is in charge of establishing the requirements of the soil cement in Cuba.

2. The bricks carried out with the sandy soil of the quarry El Globo fulfill the specifications of 
resistencia a compresión y tienen mejor comportamiento ante los ensayos de durabilidad. No obstante, las estructuras de ladrillos de suelo cemento, con contenidos de cemento del $10 \%$ o menos, siempre necesitan protección ante la lluvia y la humedad para garantizar su mayor permanencia en estado útil, dadas las condiciones climáticas de Cuba.

3. Los ladrillos producidos con el suelo Toledo se utilizarán en tabiques y paredes de carga, interiores o en exteriores, pero con protección tanto de revoques como de aleros adecuados y sobrecimientos, siempre que se hayan producido con dosificaciones de cemento entre 7,5\% y $10 \%$. Los ladrillos realizados con el suelo arenoso de la cantera El Globo, con dosificaciones desde $5 \%$ hasta $10 \%$ de cemento, cumplen las especificaciones para ser utilizados en clementos interiores y exteriores, con una protección media.

4. Los ladrillos producidos con suelo de la cantera El Globo, con dosificaciones entre 5\% y $10 \%$ de cemento, se podrán utilizar en elementos estructurales para viviendas de una a tres plantas, así como en elementos para cubiertas y entrepisos, mientras que aquellos productos con suelo de Toledo, con dosificación de 7,5 y $10 \%$ de cemento, se podran emplear en muros de carga o en separaciones. compressive strength and have better behavior than Toledo soil in under the tests of durability. Nevertheless, the soil cement bricks structures, with containing of cement of the 10\% or less, will they always need protection in front of against the rain and humidity in order to guarantee their long duration in being useful, given the climatic conditions in Cuba.

3. The bricks produced with the soil Toledo will be used in interior partitions or in external well protected, whenever they have taken place with dosages with a content of cement between the 7.5\%-10\%. The bricks carried out with the sandy floor of the quarry El Globo, with dosages of the 5\% and until the 10\% of cement, they complete the specifications in order to be used in interior and external elements, with a half protection.

4. Bricks produced with soil of the quarry El Globo, with cement containing 5\% to $10 \%$, may be used in structural elements for housings of one or two stories as well as in roofing elements and intermediate floors, while they produced with the soil Toledo with cement containing between 7.5 and $10 \%$ they may be used in loaded walls or in partitions.

\section{BIBLIOGRAFÍA}

(1) Peterssen, Gabriela y otros. Facultad de Arquitectura/CECAT. Manual de construcción con elementos de suelo cemento conformados en prensas manuales. Primera Parte. Muros. La Habana. 1994

(2) Norton, John. Building with earth. A hanbook. IT publications. 1986.

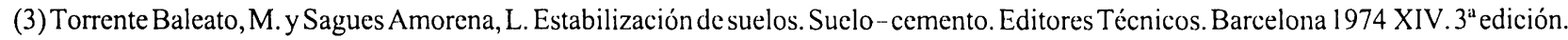
pp. 125-132.

(4) Overeas Building Note. Housing and construction information for development countries. OBN 197. EE UU. 1992.

(5) ASTM. D-559: 96. Test methods for wetting and drying compacted soil - cement mixtures. Annual book of ASTM standard. Section 4. Construction. Vol.04.08. EE UU, 1997.

(6) IT-07-91 (CODASE). Ladrillos macizos de suelo cemento. La Habana. 1991

(7) Ochoa, Elena. CEAA-Terre. CRAterre. Manual de producción de bloques de tierra comprimida. México. s/f

(8) CTVU-INV. Compendio de información sobre materiales seleccionados de bajo costo. Colección instrumentos. Red viviendo y construyendo. La Habana. 1995.

\section{Abreviaturas}

ASTM: American Sociaty Testing Materials.

CRAterre: Centro de Recherche et d'Aplicatión pour la construction en terre.

CODASE: devclopment and application soil cement comition.

CTVU: Centro Técnico de la Vivienda y el Urbanismo.

GATE: German Appropiate Technology Exchange.

H.R.B: Highway Research Board.

H y S: Humedecimiento y Secado.

INV: Instituto Nacional de la Vivienda.

$\mathrm{R}_{\mathrm{c}}$ : Resistencia a compresión.

SUCS: Sistema Unificado de Clasificación de Suelos. 